Data de recebimento do artigo: 01-08-2018

Data de aceite do artigo: $13-09-2018$

\title{
Correlations between power and affective organizational commitment
}

\author{
Arthur William Pereira da Silva \\ Doutorando em Administração na Universidade Potiguar (UnP). Professor de \\ Administração do Instituto Federal de Educação, Ciência e Tecnologia do Ceará (IFCE) - \\ Campi Jaguaruana. E-mail: arthurwilliamadm@hotmail.com (Brasil)

\begin{abstract}
Alípio Ramos Veiga Neto
Doutor em Psicologia pela Pontifícia Universidade Católica de Campinas (PUC Campinas). Coordenador do programa de doutorado em Administração, Professor no mestrado em Psicologia Organizacional e Coordenador geral de mestrados e doutorados da UnP. E-mail: alipioveiga@unp.br (Brasil)

Ana Lúcia de Araújo Lima Coelho

Doutora em Administração e Turismo pela Univali. Professora do mestrado e doutorado em Administração da Universidade Federal da Paraíba (UFPB).

E-mail: alalcoelho@gmail.com (Brasil)

Ahiram Brunni Cartaxo de Castro

Doutorando em Administração na Universidade Potiguar (UnP). Administrador no Instituto Federal de Educação, Ciência e Tecnologia do Rio Grande do Norte (IFRN).

E-mail: brunnicastro@ hotmail.com (Brasil)
\end{abstract}

\begin{abstract}
This study aims to investigate the existence of correlations between the "bases of power" and "affective organizational commitment" constructs in the Municipal Civil Guard of Mossoró/RN [GCMM]. A quantitative approach was used, which was statistical software $\mathrm{R}$, with a convenience sample of 50 civilian guards, and consisted in the analysis of the arithmetic averages, in order to reach the objectives and the Pearson correlation coefficient test. Results indicated indecision regarding the commitment in relation to the bases of power, it has been noticed that the most used by these are those of legitimate power and power of expertise, while the least used are the bases of power of coercion and reward. to the relations between the variables "bases of power" and "affective organizational commitment" in the GCMM, it was observed that they are weakly correlateds.
\end{abstract}

Keywords: Affective organizational commitment. Bases of power. Organizational commitment. Power. 


\section{Relações entre o poder e o comprometimento organizacional afetivo}

\section{Resumo}

Este estudo tem como objetivo investigar a existência de correlações entre os construtos "bases de poder" e "comprometimento organizacional afetivo" na Guarda Civil Municipal de Mossoró/RN [GCMM]. Para tanto, optou-se por uma abordagem quantitativa, a qual foi operacionalizada por meio do software estatístico R, com uma amostra por conveniência de 50 guardas civis. Assim, a análise das médias aritmética foi utilizada a fim de possibilitar o alcance dos objetivos e do teste do coeficiente de correlação de Pearson (r). Os resultados indicaram indecisão quanto ao comprometimento organizacional afetivo dos guardas civis. Em relação às bases de poder, percebeu-se que as mais utilizadas por estes são as de poder legítimo e de poder de perícia. Já as menos utilizadas, são as bases de poder de coerção e de recompensa. Quanto às relações entre as variáveis "bases de poder" e "comprometimento organizacional afetivo" na GCMM, observou-se que estão fracamente correlacionadas.

Palavras-chave: Bases de poder. Comprometimento organizacional. Comprometimento organizacional afetivo. Poder.

\section{Como referenciar em APA:}

Silva, A. W. P. da, Veiga Neto, A. R., Lima Coelho, A. L. de A., \& Castro, A. B. de (2019). Correlations between power and affective organizational commitment. R.G.Secr.,GESEC, 10(1), 91-118.

\section{Como referenciar em ABNT:}

SILVA, A. W. P.; VEIGA NETO, A. R.; LIMA COElHO, A. L. A.; CASTRO, A. B. Correlations between power and affective organizational commitment. R.G.Secr.,GESEC, São Paulo, v. 10, n. 1, p. 91-118, jan.-abr. 2019.
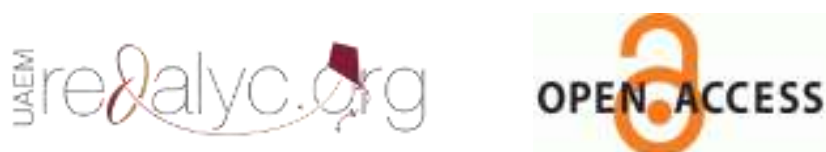


\section{Introduction}

Affective organizational commitment is one of the main determinants of worker retention in organizations (Barros \& Scheible, 2008) and this variable, like other variables that conditioning the retention process, is influenced by other organizational variables.

According to Meyer and Allen (1991), affective organizational commitment is one of the bases of organizational commitment, a broader construct composed of two additional bases - namely, the normative and the instrumental base - and concerns the worker's identification with and attachment to the organization for which he or she works.

Considering the importance of worker retention and motivation to an organization and the important role played by affective organizational commitment in worker retention, along with the fact that this variable is affected by a variety of other organizational variables, it is important to explore the relationships among these other organizational variables and affective organizational commitment to deepen our knowledge of how these relationships function. This knowledge will help researchers and especially administrators of public or private organizations to retain talent through appropriate management of the variables that determine affective organizational commitment so that they can be strategically managed to increase the level of affective organizational commitment among workers.

Taking into consideration the manner in which power is exercised in organizations, it may be one of the variables influencing the level of affective organizational commitment. The current study is based on the following research question or guiding question: Is there a relation between the type of power predominantly exercised and the level of affective organizational commitment manifested by the workers of the researched institution? In order to respond to this problem, it was established as the main objective to investigate the existence of correlations between the constructs "bases of power" and "affective organizational commitment" among the civil guards that compose the Guarda Civil Municipal de Mossoró - Municipal Civil Guard of Mossoró [GCMM] - Rio Grande do Norte, Brazil. To assist in achieving this goal, two objectives were identified: to analyze how the bases of power exercised by the GCMM are seen by members of the guard and to assess the affective commitment of civil guards to the GCMM.

It is important to point out that although the focus of this research is to explore the relations between the power and organizational commitment constructs, the organizational commitment construct is not being considered in its entirety in this study. All of which is 
composed of the three bases defined by Meyer and Allen (1991), as will be detailed subsequently, but specifically the affective organizational commitment.

\section{Theoretical Framework}

\subsection{Organizational commitment and affective organizational commitment}

In recent decades, studies of organizational behavior have focused on several topics relevant to the improvement of organizational management, including organizational climate and employee motivation and satisfaction (Traldi \& Demo, 2012; Costa \& Bastos, 2009; Siqueira \& Kurcgant, 2012; Assunção, Domingos, Cabral, Santos, \& Pessoa, 2014). However, one of the most-discussed topics in recent years is organizational commitment, given its importance to the efficiency and effectiveness of firms, the state and third-sector organizations (Barros \& Scheible, 2008; Bastos, Siqueira, Medeiros, \& Menezes, 2008; Magalhães, 2008; Feitosa \& Firmo, 2013).

Organizational behavior can be understood in various ways, and many researchers have attempted to study and define it. These researchers include Souza (2012, p. 23), who defined commitment in a simplified form as "a response to the actions taken by companies with regard to their workers"; accordingly, in this author's view, organizational commitment is a worker variable that is strongly influenced either by other organizational variables by organizational actions directed at workers, which may include the sources of power used by organizational leaders to lead workers, a relationship that is the research focus of this study.

Organizational commitment can also be understood more broadly as a set of perceptions, actions and feelings that a given worker harbors for the organization in which he or she works, and this subjective set of individual elements can determine whether the worker stays in the institution (Barros \& Scheible, 2008; Llapa-Rodríguez, Trevizan, \& Shinyashiki, 2008; Schirrmeister \& Limongi-França, 2012; Zanardi, Pilatti, Santos, Godoi, \& Claumann, 2015; Maciel \& Camargo, 2011). It is worth highlighting that in addition to defining the concept, Barros and Scheible (2008) addresses the importance of organizational commitment, stating that it is an influential factor in whether a worker will remain in the organization. Thus, returning to Souza's observation (2012) and Fernandes and Ferreira (2009) that this variable is influenced by other organizational variables and linking it to the importance Barros and Scheible (2008) attributes to organizational commitment, it is important to study the 
relationships between these various organizational variables and organizational commitment, as this study does, to guide researchers and managers in identifying these relationships and understanding how they operate.

Other authors who have attempted to conceptualize organizational commitment include Robbins, Judge and Sobral (2010), according to whom organizational commitment is related to the degree to which the worker identifies with an organization, its goals and targets, and the desire to continue participating in it. However, the two authors who are the best known for their definitions and especially for their typology of bases of organizational commitment are Meyer and Allen (1991), who define commitment as the worker's psychological state, which defines worker's relationship to his or her organization. This state of mind is sensitive to how the organization deals with its workers; in other words, it is sensitive to various organizational variables, potentially including the organization's bases of power. In addition to defining organizational commitment, these authors proposed the typology for this variable that is currently the most accepted by researchers worldwide, having been validated in several cultures. It divides organizational commitment into three bases: affective, instrumental and normative (Rowe \& Bastos, 2010; Simosi, 2013; Rodrigues \& Bastos, 2010; Botelho \& Paiva, 2011; Paiva \& Morais, 2012; Paiva, Dutra, \& Luz, 2015).

The first of the three bases of organizational commitment defined by Meyer and Allen (1991) is affective organizational commitment, which refers to the worker's identification with his or her organization, along with his or her level of emotional connection to that organization. The second base of organizational commitment is instrumental organizational commitment, which refers to the cost-benefit analysis of leaving the organization; that is, the worker will remain in the organization as long as the costs of leaving outweigh the benefits. Finally, the third base of organizational commitment is normative organizational commitment, which refers to the subjective sense of "duty" a worker may feel to remain in the organization, to carry out his or her activities in the organization, and to contribute to the achievement of organizational goals (Feitosa \& Firmo, 2013; Reinert, Maciel, \& Candatten, 2011).

Thus, the focus of this study will be to explore the relationships between the constructs of power and organizational commitment; but instead of addressing organizational commitment as a whole, composed of the three bases defined by Meyer and Allen (1991), this study will focus on affective organizational commitment. 


\subsection{Power in Organizations}

There are many definitions of power, all of which have something in common: most theorists agree that power arises from social relations because the existence of a power relationship requires a dominated party (individual or group) and a dominant party (individual or group) (Guimarães \& Martins, 2008). Santos (2002) offers the following definition: "power is the ability of an individual or group to obtain mastery or control over others." Another succinct definition of power is given by Dahl (1957, pp. 202-203), according to whom "A has power over B to the extent that he can force B to do something that B would not otherwise have done."

These concepts are obvious in the organizational environment, as the owners or the government (the dominant group) make use of this ability to influence workers (the dominated group) to carry out activities necessary to achieve the organizational goals, which, in large part, are the objectives of the owners or government. This dominant/dominated relationship is not as static as it appears: the owner or state is not always dominant, and at times workers are able to draw on sources of power to revert the situation, forcing the dominant party to accede to some points, thereby gradually inserting their individual objectives into the organization's objectives. As a result, however, this power game is always more favorable to the stronger party in the relationship.

The leading studies on power in the organizational setting have evolved over time to take the following forms, according to Morgan (2000), Marx (2006), Martins (2008), Paz and Neiva (2014) and Fleming and Spicer (2014):

Firstly, Table 1 presents the main approaches to power in its political tendency, that is, power as a means used in political activities.

Table 1 - Power as a political dimension

\begin{tabular}{|l|l|l|}
\hline \multicolumn{1}{|c|}{$\begin{array}{c}\text { Author/Time } \\
\text { Period }\end{array}$} & \multicolumn{1}{|c|}{ Concept } & \multicolumn{1}{c|}{ Essence } \\
\hline $\begin{array}{l}\text { Maquiavel } \\
{[1532 / 1972]}\end{array}$ & $\begin{array}{l}\text { Introduced the concept based on an analysis of the strategies } \\
\text { for exercising and maintaining power. The author proposes } \\
\text { that power is a phenomenon that involves a diffuse network, } \\
\text { a chain of power. Power is ephemeral and passes through } \\
\text { people. }\end{array}$ & $\begin{array}{l}\text { - Diffuse network } \\
\text { - Ephemeral }\end{array}$ \\
\hline $\begin{array}{l}\text { Hobbes } \\
{[1651 / 1988]}\end{array}$ & $\begin{array}{l}\text { Power resides in the means employed to obtain apparent } \\
\text { future advantage: war ceases only when all have been } \\
\text { subjugated to state power. }\end{array}$ & future advantages \\
\hline
\end{tabular}


Silva, A. W. P. da, Veiga Neto, A. R., Lima Coelho, A. L. de A., \& Castro, A. B. de (2019)

\begin{tabular}{|l|l|l|}
\hline Marx [2006] & $\begin{array}{l}\text { Power derives from a social class position in the relations of } \\
\text { production, such as possession and control of the means of } \\
\text { production by the capitalist class. From this perspective, the } \\
\text { importance of power lies not in individual relationships, but } \\
\text { in the domination and subordination of social classes based } \\
\text { on the relations of production. }\end{array}$ & $\begin{array}{l}\text {-Social classes } \\
\text {-Relations of } \\
\text { production }\end{array}$ \\
-Domination/ \\
Subordination
\end{tabular}

Source: Prepared by the authors, 2017.

Table 2 shows some key elements for understanding power in its political dimension: the exercise of power is a strategy made possible through a diffuse network to obtain future advantages through forms of legitimate domination that legitimize a society of social classes, whereas the relations of production are formed by domination/subordination and political systems are organized by interest, conflicts and power.

Table 2 - Power from a behavioral perspective

\begin{tabular}{|l|l|l|}
\hline $\begin{array}{l}\text { Author/Time } \\
\text { Period }\end{array}$ & \multicolumn{1}{|c|}{ Concept } & Essence \\
\hline Dahl [1957] & $\begin{array}{l}\text { The power of influence: A has power over B to the extent that A can } \\
\text { influence B to do something that B would not otherwise do. }\end{array}$ & - Influence \\
\hline $\begin{array}{l}\text { French and Raven } \\
{[1959] \text { and Raven }} \\
{[1993]}\end{array}$ & $\begin{array}{l}\text { Relations among people were based on social exchanges, and these } \\
\text { exchanges were based on relations of influence: a person was supported } \\
\text { by exercising power over another. The authors introduced five bases of } \\
\text { power: reward (rewarding or removing/reducing punishments), } \\
\text { coercion (controlling something that is important to the other), }\end{array}$ & exchanges \\
\hline
\end{tabular}




\begin{tabular}{|l|l|l|}
\hline & $\begin{array}{l}\text { legitimate (legal power), expert (mastery of knowledge) and referent } \\
\text { (based on belief in a model). These authors' proposal was introduced to } \\
\text { organizational studies to examine the relationship between supervisor } \\
\text { and employee. }\end{array}$ & \\
\hline Luke [1980] & $\begin{array}{l}\text { Power lies in the idea of interests: A exercises power over B when A } \\
\text { affects B in a manner that is contrary to B's interests. }\end{array}$ & - Interest \\
\hline
\end{tabular}

Source: Prepared by the authors, 2017.

Table 3 shows the behavioral perspective on power that consists of influence (domination) and favoring the interests of some over others through the ability to reward, the ability to coerce, legally established power, expertise and the influence of a reference model, from the perspective of research into the relationship between supervisor and employee.

Table 3 - Power from the dominant groups perspective and from the organizational perspective

\begin{tabular}{|c|c|c|}
\hline Author/Time Period & Concept & Essence \\
\hline Mintzberg [1983] & $\begin{array}{l}\text { Sought to explain the organization's dynamic by focusing on } \\
\text { power at the levels of the individual and the collective, internal } \\
\text { and external, within and between groups, considering } \\
\text { organizational behavior and power as a game in which various } \\
\text { players (influencers) attempt to control the organizational } \\
\text { actions. }\end{array}$ & - Influence \\
\hline $\begin{array}{l}\text { Schriesheim, Hinkin } \\
\text { and Podsakoff [1991] }\end{array}$ & $\begin{array}{l}\text { Using factorial analysis, these authors validated a scale called the } \\
\text { Supervisor's Power Bases Scale to eliminate the subjectivity } \\
\text { present in French and Raven's proposal. }\end{array}$ & $\begin{array}{l}\text {-Scale for } \\
\text { measuring the } \\
\text { power of dominant } \\
\text { groups }\end{array}$ \\
\hline Yukl [1994] & $\begin{array}{l}\text { Discovered that the bases of power proposed by French and } \\
\text { Raven have an impact on the worker's organizational } \\
\text { commitment, trust and resistance. }\end{array}$ & $\begin{array}{l}\text {-Organizational } \\
\text { commitment }\end{array}$ \\
\hline Coda [1997] & Discussed how power influences the organizational climate. & $\begin{array}{l}\text {-Organizational } \\
\text { climate }\end{array}$ \\
\hline $\begin{array}{l}\text { Johnson and Scollay } \\
\text { [2000] }\end{array}$ & $\begin{array}{l}\text { Introduced the idea that bases of power affect conflicts and } \\
\text { influence within groups and organizations. }\end{array}$ & $\begin{array}{l}\text {-Conflict } \\
\text { - Influence }\end{array}$ \\
\hline
\end{tabular}

Source: Prepared by the authors, 2017.

Table 3 shows the perspective of power through conflict among dominant groups or organizations, seeking to understand how one influences the other and how this affects the game in which several groups attempt to control organizations, along with the impact on the dominated in constructs involving organizational commitment and organizational climate.

Therefore, most academic studies of power in the organizational sphere adopt a positivist, functionalist and structuralist point of reference (Cappelle, Melo, \& Brito, 2005). This trend is continuing and rests on discussions that continue to address typologies of power (Raven, 1993; Mendonça \& Dias, 2006; Weber, 2008), the validation and evaluation of scales related to power and how it is structured in organizations (Martins, 2008; Paz \& Neiva, 2014), 
organizational actors who draw on resources to exercise power, ownership of the means of production, location, class position or technical knowledge, whether in the organization or in society (Saraiva \& Santos, 2011), how power relates to the ownership of resources, governance, and the origin of conflicts (Giglio, Pugliese, \& Silva, 2012), the use of power in social networks (Rosa \& Kamimura, 2012), power over, learning about and sharing organizational knowledge (Fahy, Easterby-Smith, \& Lervik, 2013), relations of power in family organizations (Lopes, Carrieri, \& Saraiva, 2013), power and policy in organizations (Santos \& Claro, 2014), and relations of power and gender in organizations (Ribeiro \& Garcia, 2015). Thus, power lies in the political, individual, group and organizational dimensions.

\subsubsection{Bases of power employed in this study}

To exercise power over another, an individual must have elements that give him or her this power, and these elements are referred to as either bases or sources of power. There are many sources of power, and each analytical approach presents a series of them. Although these sources of power vary in nature, all share a common goal: to influence the dominated to do the will of the dominant. As discussed in the previous section and in Table 2, which presents the authors who address power from a behavioral perspective, French and Raven (1959) developed a theory about social power. This theory holds that relations between people are based on exchanges, with emphasis on relationships of influence, sustained by five bases of power. Power, categorized as reward power, coercive power, legitimate power, expert power and referent power, was defined by the authors as the bases of support used by an individual to exert power over another. Table 4 shows the characteristics of each of these types of power. 
Table 4 - Bases of power, according to French and Raven (1959)

\begin{tabular}{|l|l|l|l|l|}
\hline $\begin{array}{l}\text { Reward } \\
\text { Power }\end{array}$ & Coercive Power & Legitimate Power & Expert Power & Referent Power \\
\hline $\begin{array}{l}\text { Based on the } \\
\text { ability to } \\
\text { reward }\end{array}$ & $\begin{array}{l}\text { Involves the } \\
\text { individual's ability to } \\
\text { control something } \\
\text { important to the } \\
\text { other. Coercive } \\
\text { power is based on a } \\
\text { person's expectation } \\
\text { that he or she will be } \\
\text { punished by the other } \\
\text { for failure. }\end{array}$ & $\begin{array}{l}\text { Recognition by a } \\
\text { person that } \\
\text { another's power is } \\
\text { legally constituted } \\
\text { and that he or she } \\
\text { has a duty to accept } \\
\text { this influence. }\end{array}$ & $\begin{array}{l}\text { Based on recognition } \\
\text { that another possesses } \\
\text { knowledge or expertise } \\
\text { in a particular subject } \\
\text { and therefore should } \\
\text { not be questioned. }\end{array}$ & $\begin{array}{l}\text { Power to influence } \\
\text { others through } \\
\text { strength of } \\
\text { charisma or } \\
\text { personal } \\
\text { characteristics that } \\
\text { are admired and } \\
\text { considered a } \\
\text { reference. }\end{array}$ \\
\hline
\end{tabular}

Source: Prepared by the authors, 2017.

Each form of power is derived from an assumption based on relations among people, whether they are good or bad forms of relations. The authors believe there are many other bases of power that should be identified and studied.

Hinkin and Schriesheim (1989, p. 561), for example, note that "although many typologies or models exist, French and Raven's is perhaps the most influential." For that reason, French and Raven's typology of bases of power was chosen as the basis for this study.

It is interesting to note that in general terms, legitimate and expert bases of power are considered beneficial to the organization: according to Yukl (1994), they are positively related to organizational commitment and trust, and according to Rahim (1989), they are positively related to the worker's level of trust. However, the coercion and reward bases of power are widely considered harmful to the organization: they are associated with resistance, which is characterized as a form of organizational conflict (Johnson \& Evans, 1997).

\subsection{The Municipal Civil Guard of Mossoró-RN}

To explore the relationship between power and affective organizational commitment, the GCMM was chosen as an object of study. This choice was motivated by the fact that the GCMM is a medium-sized organization with a large workforce composed of individuals from very heterogeneous socioeconomic backgrounds; the organization experiences constant power conflicts throughout its hierarchy, making it fertile ground for this study's analyses. 
Silva, A. W. P. da, Veiga Neto, A. R., Lima Coelho, A. L. de A., \& Castro, A. B. de (2019)

The GCMM was established in 2009 by complementary law no. 37 of December 14, 2009 (Mossoró, 2009), and now employs approximately 275 full-time municipal civil guards in addition to an appointed administrative staff.

From 2009 to May 2016, the organizational (operational) structure of the GCMM can be summarized as consisting of the commander (at the top of the hierarchy), followed by supervisors who command the institution's eight platoons, followed by civil guards. The only criterion for the supervisors' appointment to leadership positions was political patronage. However, in 2014, the GCMM's Employment, Career and Salary Plan (Plano de Cargos, Carreira e Remunerações, or PCCR) was established by complementary law no. 98 of January 24, 2014 (Mossoró, 2014), which determined criteria for appointing the institution's platoon leaders. According to the PCCR, these leaders are designated inspectors and sub-inspectors and should rise to leadership positions through an internal selection process composed of four stages: length of service; level of education; vocational courses in the field of public safety; and a physical endurance test.

The PCCR was developed by the union in 2012 and 2013 and was approved and established through negotiations following a labor strike called by the union in 2013. The selection process took place in May 2016, and in June of that year those chosen were appointed and assumed their duties, replacing the supervisors.

The GCMM workforce is divided into eight platoons, which are shown in Figure 6 in the discussion and analysis section.

\section{Methodology}

\subsection{Study type}

This study is descriptive and exploratory in nature. It is descriptive in that it seeks to reveal the studied group's characteristics, such as the extent to which the workers report that each power base is employed in the institution and civil guards' level of affective organizational commitment civil guards toward the organization (Sampieri, Collado, \& Lucio, 2006). It is exploratory in that this study aims to conduct a detailed exploration of the statistical relationships between power and affective organizational commitment and deepen knowledge 
about the relationship between these two constructs in Brazilian public organizations in the field of public safety (Sampieri, Collado, \& Lucio, 2006).

The samples were coded for statistical analysis. Each worker was considered a sampling unit, and each question was considered a variable. Thus, the matrix of multivariate data consisted of 50 sampling units and 45 variables. Taking the answers to these questions as references, the tests, which will be discussed later, were conducted. The data were analyzed quantitatively.

\subsection{Sample}

The organization studied was the Municipal Civil Guard of Mossoró, a city located in the state of Rio Grande do Norte, Brazil, $280 \mathrm{~km}$ from the state capital of Natal. The organization currently has 275 guards, 50 of whom (18\%) participated in the study.

Respondents were selected by convenience, i.e., based on access to respondents, excluding guards who held positions as supervisors, inspectors or sub-inspectors, to preserve the reliability of the answers to the maximum extent.

\subsection{Data collection}

To conduct this study, documentary research was undertaken to gather relevant information about the Municipal Civil Guard of Mossoró, including analysis of the institution's website and laws that regulate the institution (such as, inter alia, complementary law no. 37 and complementary law no. 98).

A structured questionnaire was also applied. That questionnaire was composed of 26 closed questions, of which 4 questions related to socioeconomic characteristics (elaborated by the authors); 2 questions related to length of service and area of activity in the civil guard (elaborated by the authors); and 15 questions related to measuring how leadership uses the bases of power. To this end, the study employed Martins' (2008) Supervisor's Power Bases Scale [Escala de Bases do Poder do Supervisor, or EBPS], which has been extensively validated at the international level and subsequently, for use in Brazil, having been tested statistically with 312 Brazilian workers in various types of organizations.

As adapted and validated for use with Brazilian workers, the EBPS assesses four of the fives bases of power proposed by French and Raven (1959), namely, legitimate, expertise, 
coercive and reward power bases. The five bases of power were used to assess the level of affective organizational commitment among the institution's workers; to this end, the Affective Organizational Commitment Scale [Escala de Comprometimento Organizacional Afetivo, or ECOA] developed by Bastos, Siqueira, Medeiros and Menezes (2008) was applied. We applied the short version of the scale, which contains five questions to be answered on a five-point Likert scale; the reliability index (Cronbach's $\alpha$ ) for this version is 0.93 .

Finally, the participant observation method was used because one of the authors of this study works in the institution as a municipal civil guard and thereby has direct and continuous contact with the subjects of the study. This method was used primarily to collect data relevant to the GCMM that were not available through documentary research.

\subsection{Method of analysis}

Quantitative analysis of the data was undertaken using bivariate statistical analysis. The results were tabulated using Microsoft Excel, and the R statistical program was used to analyze the data. First, a descriptive analysis of the socioeconomic data obtained with questionnaires was developed.

The following methods were adopted to achieve this study's two objectives proposed in addition to the primary aim. To analyze the data relating to the objective of analyzing the bases of power exercised by the GCMM leadership as perceived by the workers, the factor means were scaled, one for each basis of power measured. To achieve the objective of assessing the affective commitment of the civil guards of the GCMM, the arithmetic mean of the data obtained was calculated. The analysis of the data is in line with what is recommended by the authors of the scales, namely, EBPS (Martins, 2008) and ECOA (Bastos, Siqueira, Medeiros, \& Menezes, 2008).

Pearson's correlation coefficient (r) was used to achieve the primary aim of this study, which was to determine whether there are correlations between the constructs "bases of power" and "affective organizational commitment" among the civil guards who comprise the GCMM. This measurement assesses the strength and direction of linear correlation between the two variables (Hair, William, Babin, \& Anderson, 2009). 


\section{Analysis and Disscussion}

\subsection{Sample description}

The study sample is composed of 50 individuals, representing $18.2 \%$ of the 275 civil guards who compose the GCMM. According to the responses, the majority of respondents (62\%) have worked at the institution for less than one year; $16 \%$ are female and $84 \%$ are male; some of the respondents have completed secondary education (high school) (32\%), whereas the majority (68\%) have college or graduate degrees; household income generally ranged between $\mathrm{R} \$ 2,000.00$ and $\mathrm{R} \$ 3,000.00$ (36\%); and the mean age was 32. These characteristics indicate that the sample is adequate for the analytical procedures. The sociodemographic characteristics of the sample are summarized in Figures 1-6.

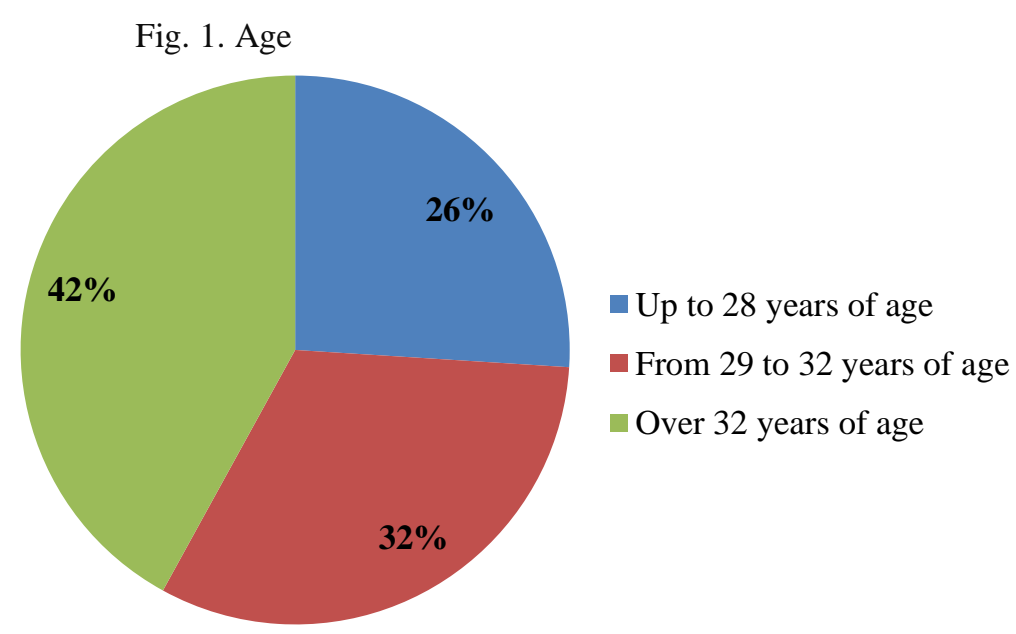

Source: Author's own work, 2017.

As shown in Figure 1 and based on an analysis of the mean age, 32, and the standard deviation from this mean, which is only 6 years, there is a concentration around the mean, meaning most of the civil guards who answered the questionnaire were of a similar age. 
Fig. 2. Gender

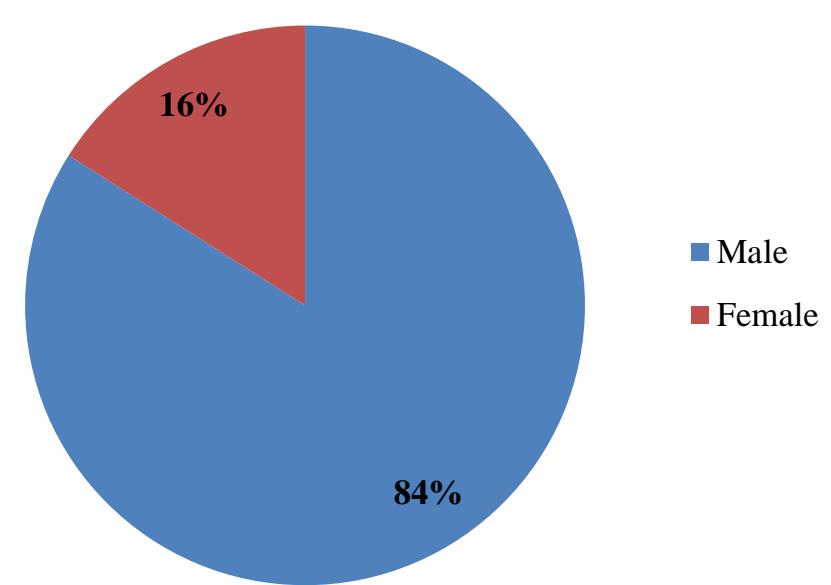

Source: Author's own work, 2017.

Based on the method of participant observation, it was found that the obvious prevalence of men may be primarily attributable, inter alia, to the nature of the daily activity and the high risk to life entailed by that activity.

Fig. 3. Level of education

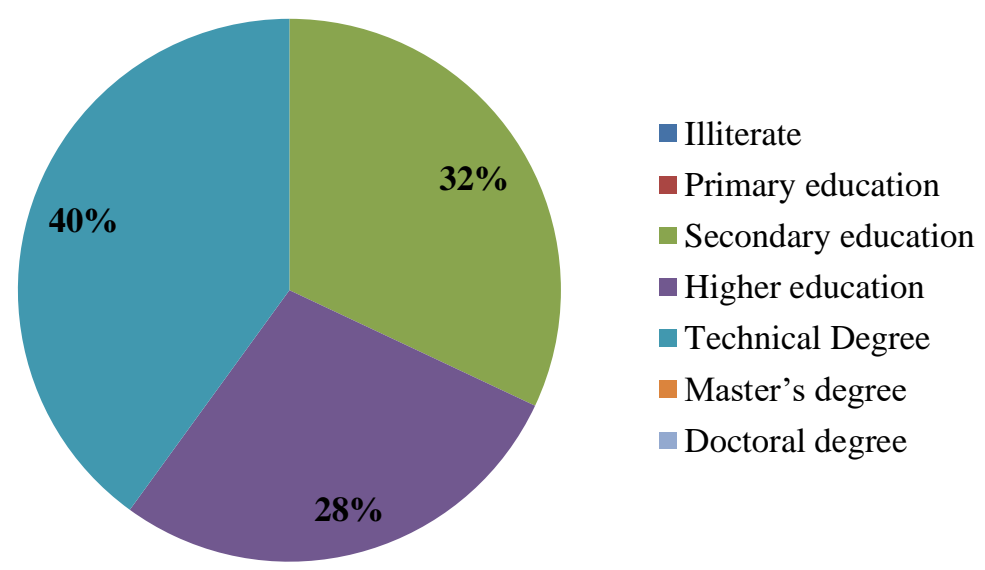

Source: Author's own work, 2017.

Participant observation also revealed that one of the main factors accounting for the high number of civil guards with advanced education is the existence of an article in the Employment, Career and Compensation Plan [PCCR] that provides for career advancement and salary increases as workers acquire more education, progressing from a high school diploma to a doctoral degree. 
Fig. 4. Range of household monthly income

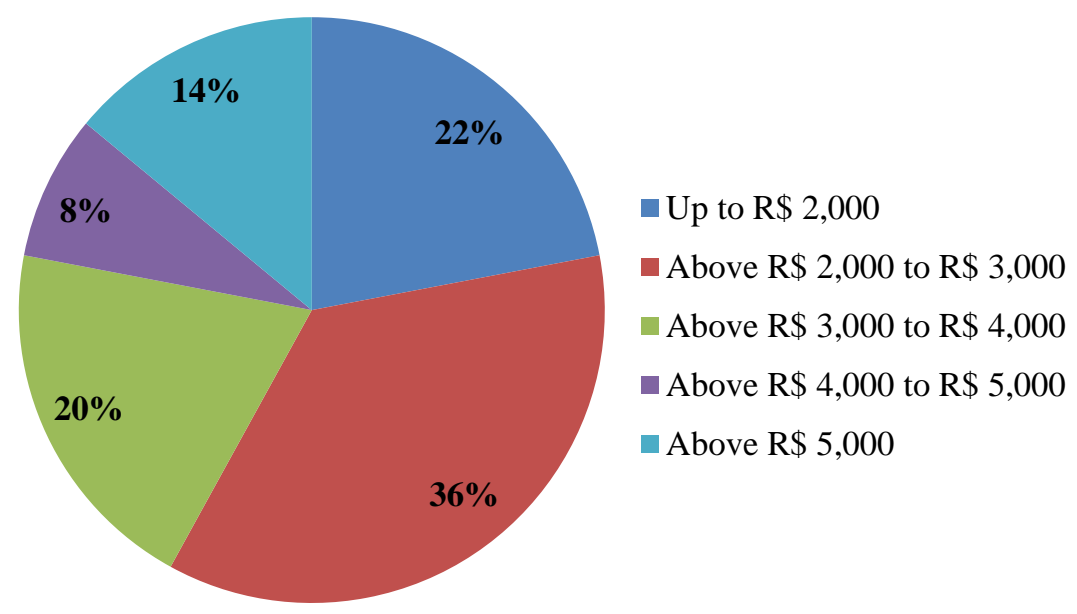

Source: Author's own work, 2017.

It was also noted through participant observation that the differences in the level of income earned by respondents who all hold the same job is attributable, inter alia, to academic progression and length of service (which result in higher pay) and to overtime.

Fig. 5. Distribution of the respondents by platoon

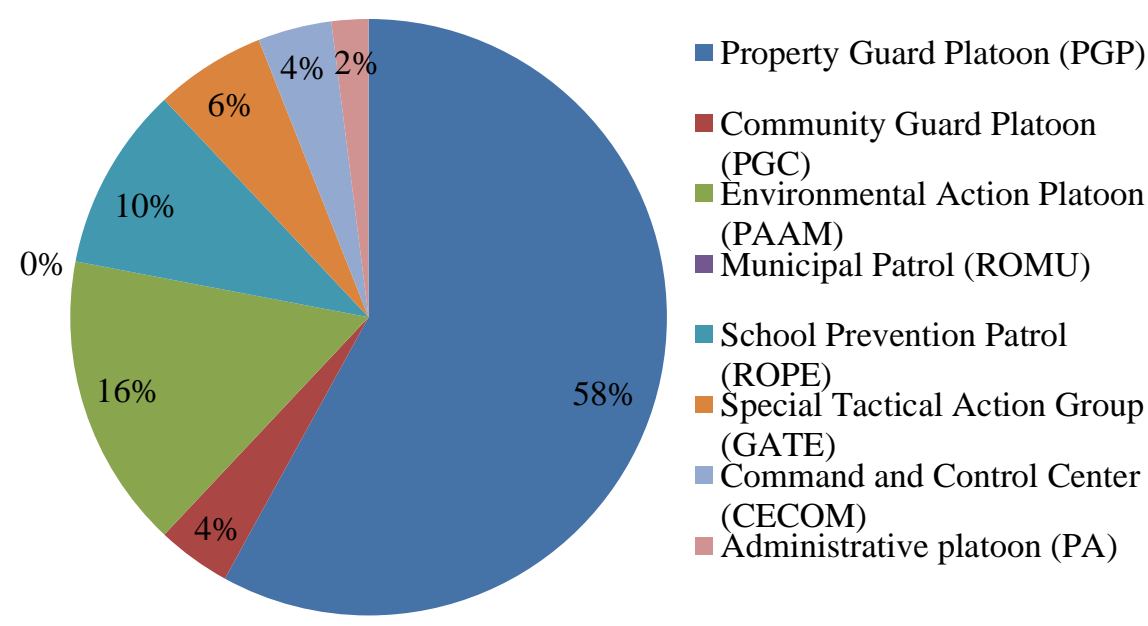

Source: Author's own work, 2017.

As mentioned above, the GCMM is subdivided into the following eight platoons: the Public Property Guard Platoon [PGP]; the Community Guard Platoon [PGC]; the Environmental Action Platoon [PAAM]; the Municipal Patrol [ROMU]; the School Prevention Patrol [ROPE]; the Special Tactical Action Group [GATE]; the Command and Control Center $[\mathrm{CECOM}]$ and the Administrative Platoon [PA]. The large number of respondents belonging to the PGP can be explained by the size of that platoon, which has the largest number of guards. 
Fig. 6. Length of service

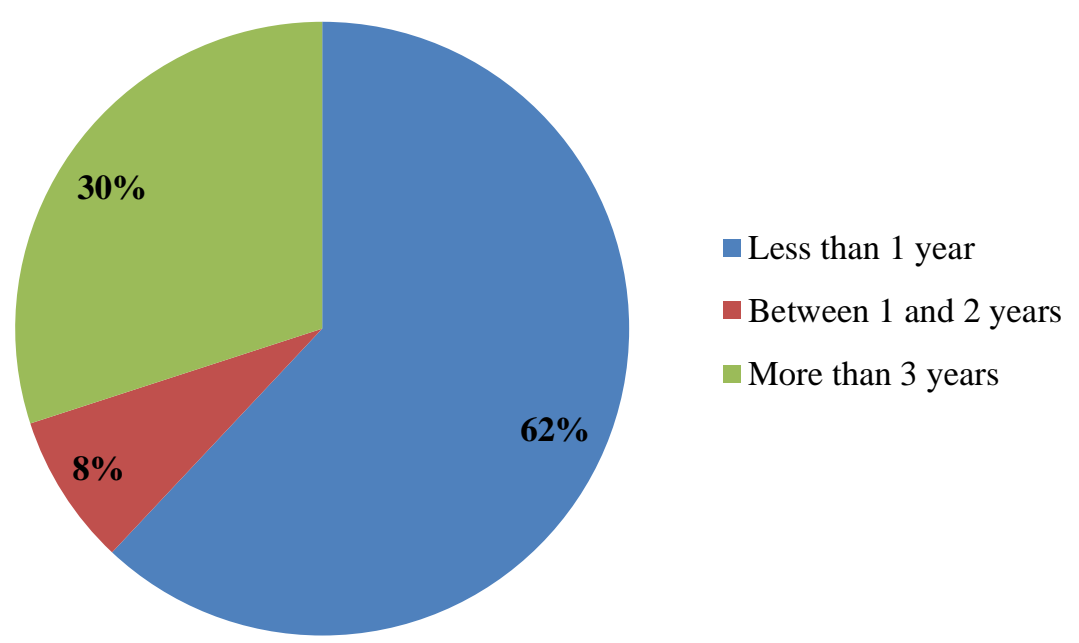

Source: Author's own work, 2017.

The fact that most respondents were relatively new members of the organization can be explained by, among other factors, the recent establishment of the GCMM (2009) and the fact that most of the respondents were hired through the selection process (2010).

\subsection{Analysis of the affective organizational commitment in the GCMM}

Measurement of the affective organizational commitment of the civil guards in the GCMM using the ECOA indicated an arithmetic mean of 3.288. With respect to interpreting this mean, Bastos, Siqueira, Medeiros and Menezes (2008, p. 58) state that the greater the value of the mean score, the stronger the affective commitment to the organization. They also state that: "Scores of 4 and 5 may indicate that the worker feels affectively committed to the organization. Scores between 3 and 3.9 suggest the employee is undecided about the affective bond. Scores between 1 and 2.9 may indicate weak affective commitment to the organization."

In light of the results obtained and the reference parameters proposed by Bastos, Siqueira, Medeiros and Menezes (2008), it appears that these affective commitment scores suggest that municipal civil guards are indecisive about their affective commitment to the GCMM as an institution. It is worth emphasizing that the observed score falls very close to the upper limit of the range identified as weak affective commitment to the organization, which ranges from 1 to 2.9 . 
Based on Barros and Scheible affirmation (2008) of the importance of organizational commitment as a factor determining whether a worker will stay in the organization, and considering the level of affective organizational commitment that the civil guards demonstrated for the GCMM, which was in the range of indecision bordering on indifference, the institution's management must analyze the variables that can affect this commitment if they want to improve their administration, increase the level of the guards' affective commitment, retain these safety agents and keep them motivated to perform their duties, which involve high risk and are of great value to society.

\subsection{Analysis of the use of the bases of power in the GCMM}

Table 5 presents the results, using means, of how the GCMM's leaders (inspectors and sub-inspectors) use the four bases of power included in the Supervisor's Power Bases Scale of Martins (2008).

Table 5 - Means of the bases of power

\begin{tabular}{cc}
\hline Basis of Power & Mean \\
\hline Power based on legitimacy & 3.65 \\
Power based on expertise & 3.66 \\
Power based on coercion & 2.17 \\
Power based on reward & 2.10 \\
\hline
\end{tabular}

Source: Prepared by the authors, 2017.

The scale ranges from 1 to 5, with the following levels of analysis: Values greater than 4 indicate that this basis of power is used extensively and values lower than 2.9 indicate that the basis is used infrequently.

Power based on legitimacy, that is, power based on what Martins (2008, p. 22) describe as "an individual's recognition that the other has legally established power to influence him and that he has a duty to accept this influence" (i.e., power based on others' acceptance of one's leadership) is used to a moderate degree by leaders of the GCMM, approaching an intense degree in the view of those they lead.

Power based on expertise, that is, power based on what Martins (2008), describe as "an individual's recognition that the other has a certain expert knowledge and therefore should not 
be questioned," is also used to a moderate degree by leaders of the GCMM, approaching an intense degree in the view of those they lead.

Power based on coercion, that is, power based on what Martins (2008, p. 22), describe as "an individual's capacity to control things of importance that threaten the other," is infrequently used by leaders of the GCMM, in the view of those they lead.

Finally, power based on reward, that is, power based on what Martins (2008) describe as "the ability to provide another person something considered a prize, or to remove or reduce the other's punishment," is also infrequently used by leaders of the GCMM, in the view of those they lead.

In general, the diagnosis of the use of the four bases of power in Martins' (2008) Supervisor's Power Bases Scale [EBPS] shows that the institution's leadership relies most heavily on two of these bases-legitimacy and expertise-which are beneficial to the organization in that according to Yukl (1994), they are positively correlated with organizational commitment and trust, and according to Rahim (1989), they are positively correlated with the worker's level of trust.

It also shows that the two bases of power upon which the leadership are least reliantcoercion and reward - are harmful to the organization in that according to Johnson and Evans (1997), they are associated with resistance, which they consider a form of organizational conflict.

\subsection{Analysis of correlations between power and affective organizational commitment in the GCMM}

To assess and explore the existence and level of possible correlations between the civil guards' organizational commitment and each of the bases of power used by the institution's leadership, the Pearson correlation coefficient (r) among these variables was calculated. The results of testing the correlation using the R statistical program are shown in Table 6.

Table 6 - Correlations between power and affective organizational commitment

\begin{tabular}{cc}
\hline Bases of Power & Correlations \\
\hline Power based on legitimacy & 0.1437515 \\
Power based on expertise & -0.0326738 \\
Power based on coercion & 0.06381996 \\
\hline
\end{tabular}


Source: Prepared by the authors, 2017.

With regard to interpreting Pearson's linear correlation coefficient of Pearson, Hair, Anderson, Tathan and Black (2005) explain that the degree of linear statistical dependence between variables increases as the value approaches one, independently of the sign, which indicates the direction of the correlation. Hair, Anderson, Tathan and Black (2005) suggest that values between 0.1 and 0.3 can be considered indicators of a weak correlation, values between 0.4 and 0.6 reflect a moderate correlation, and values between 0.7 and 1 indicate a strong linear correlation. Hair, Anderson, Tathan and Black (2005) state that a positive sign indicates the correlation between the variables in positive, that is, high values of one variable are associated with high values of the other variable, and low values of one variable are associated with low values of the other variable; a negative sign, on the other hand, indicates a negative correlation between the variables.

Based on the parameters indicated by Hair, Anderson, Tathan and Black (2005), the following observations can be made with regard to the results of the correlations.

One of the bases of power shown to be most closely correlated with affective organizational commitment was reward, with $\mathrm{r}=-0.1680667$, although this correlation was negative, meaning the more civil guards perceived leaders as using reward as the basis for their power, the less affective commitment they felt to the institution. However, it should be noted that according to the parameters proposed by Hair, Anderson, Tathan and Black (2005), despite being the base of power that is the most correlated with affective organizational commitment, the correlation between the two variables is weak.

The base that showed the second greatest correlation with affective organizational commitment was legitimacy, with $r=0.1437515$, and in this case the correlation was positive, meaning the greater the guard's perception that their leaders are exercising legitimate power, the greater their affective organizational commitment to the institution. However, as with the correlation for power based on reward, the correlation between power based on legitimacy and affective organizational commitment was weak.

The bases of power most weakly correlated with affective organizational commitment were the bases of coercion and expertise. The correlation with power based on coercion was $r$ $=0.06381996$ and the correlation with power based on expertise was $r=-0.0326738$. It should be noted that there was a difference in direction, or sign, in the correlations, showing that power 
based on coercion is positively correlated to affective organizational commitment and power based on expertise was negatively correlated to affective organizational commitment. It is important to stress that these bases of power showed the weakest correlation with affective organizational commitment by the criterion proposed by Hair, Anderson, Tathan and Black (2005).

Analysis of the results shows that the variables "bases of power" and "affective organizational commitment" have only a weak linear correlation, at least among the subjects of this study, considering that no correlation was found to have a Pearson's $r$ between 0.4 and 0.6 , nor between 0.7 and 1, which represent moderate or strong correlations, respectively, according the parameters given by Hair, Anderson, Tathan and Black (2005).

The results and analyses of this study do not support Yukl's argument (1994) that the bases of power proposed by French and Raven have an impact on organizational commitment as a whole.

However, although they do not support Yukl's proposal (1994), the results and analysis of this study are similar to the results found by Porto, Vasconcelos, Silva and Paulino (2010) and Rosário, Queiroz and Martins (2015).

In a study conducted with a sample of 113 workers at micro, small, medium-sized and large companies in the trade or service sector of João Pessoa in the State of Paraíba, Brazil, Porto, Vasconcelos, Silva and Paulino (2010) found that affective organizational commitment correlated positively only with the legitimacy basis of power; all the other bases of power correlated negatively, and the correlation with all bases of power was weak.

A study conducted by Rosário, Queiroz and Martins (2015) with a sample of 125 administrative technicians in a public institution of higher education in the State of Rio Grande North, Brazil, identified only weak positive correlations, with the exception of the coercion basis of power, which showed a weak and negative correlation. That study found a weak linear correlation between the variables of "power" and "affective commitment" among the respondents.

\section{Final Considerations}

The results obtained with respect to the affective organizational commitment of civil guards in the GCMM indicate a need for the institution's management both to analyze which 
variables can affect the guards' sense of identification with the institution and to take steps to better manage those variables, given that the mean value found for affective organizational commitment among the guards was in the range identified by Bastos, Siqueira, Medeiros and Menezes (2008) as indicating indecision bordering on indifference with regard to their affective commitment to the organization. They should also consider the importance attributed by Barros and Scheible (2008) to affective organizational commitment as a key to maintaining safety officers in the institution and motivating them to perform their jobs on a daily basis.

With regard to the analysis of the bases of power exercised by the GCMM management in their workers' view, based on the conceptual relationship established in the theoretical framework between French and Raven's (1959) bases of power and Schein's (1982) two forms of authority, it can be seen that with the two bases of power most employed by the leadersthe legitimate and the expert bases of power-the GCMM much more closely resembles the model of legitimate authority, which according to Schein (1982) is based on the leader's acceptance by the team instead of on the use of coercive instruments, than it resembles the model of illegitimate authority, which relies on coercion, brute force and the use of rewards, punishment and information to control people, and in which coercion and reward are the bases of power.

With regard to the analysis of the correlations between the constructs "bases of power" and "affective organizational commitment" among the civil guards that compose the GCMM, although it is impossible to generalize the results obtained, due to, inter alia, the nonprobabilistic sample and the fact that the results do not confirm Yukl (1994), the similarities found between the results of this study and the results obtained by Porto, Vasconcelos, Silva and Paulino (2010) and Rosário, Queiroz and Martins (2015), who conducted similar studies in Brazil's private and public sectors, respectively, suggest at least the possibility that the variables "bases of power" and "affective organizational commitment " actually have only weak linear correlations.

Finally, the most significant limitation of this study relates to the sample, which was chosen by convenience because of the difficulty of gaining access to the civil guards, as they work in shifts in public buildings scattered throughout the city and in mobile patrol cars. It is suggested that future studies explore the existence and intensity of possible correlations between the variables examined in this study, including different types of organizations and more representative samples, chosen (if possible) at random. 


\section{References}

Arendt, H. (1958). The Human Condition (2nd ed.). Chicago: University of Chicago Press.

Arendt, H. (1970). On violence. Orlando: Harcourt Brace Jovanovich.

Assunção, R. R., Domingos, S. R. M., Cabral, A. C. A., Santos, S. M., \& Pessoa, M. N. M. (2014). Satisfação e comprometimento organizacional afetivo: um estudo com docentes universitários do curso de Ciências Contábeis. ReA UFSM, 7(3), 453-468. doi:10.5902/198346597588

Barros, A. R. O., \& Scheible, A. C. F. (2008,embro). Comprometimento organizacional: um estudo de suas relações com práticas de gestão e intenção de permanência. Anais do Encontro de Administração da ANPAD - ENANPAD. Rio de Janeiro, RJ, Brasil, 32.

Bastos, A. V. B., Siqueira, M. M. M., Medeiros, C. A. F., \& Menezes, I. G. (2008). Comprometimento organizacional. In M. M. M. Siqueira (Org.), Medidas do comportamento organizacional (pp. 49-95). Porto Alegre: Artmed.

Botelho, R. D., \& Paiva, K. C. M. (2011). Comprometimento organizacional: um estudo no Tribunal de Justiça do Estado de Minas Gerais. RAP, 45(5), 1249-1283. doi:10.1590/S0034-76122011000500002

Cappelle, M. C. A., Melo, M. C. O. L., \& Brito, M. J. (2005). Relações de poder segundo Bourdieu e Foucault: uma proposta de articulação teórica para a análise das organizações. Organizações Rurais e Agroindustriais, 7(3), 356-369. Recuperado de http://200.131.250.22/revistadae/index.php/ora/article/view/193/190

Coda, R. (1997). Pesquisa de clima organizacional e gestão estratégica de recursos humanos. In: M. C. Bergamini, \& R. Coda. (Orgs.). Psicodinâmica da vida organizacional: motivação e liderança (2a ed.). São Paulo: Atlas.

Costa, F. M., \& Bastos, A. V. B. (2009). Múltiplos comprometimentos no trabalho: um estudo entre trabalhadores de organizações agrícolas do polo de fruticultura irrigada de Juazeiro/Petrolina. ReA UFSM, 2(2), 280-297. doi:10.5902/198346591557

Dahl, R. A. (1957). The Concept of Power. Connecticut: Yale University.

Fahy, K. M., Easterby-Smith, M., \& Lervik, J. E. (2013). The power of spatial and temporal orderings in organizational learning. Management Learning, 45 (2), 123-144. doi:10.1177/1350507612471925 
Feitosa, M. J. S., \& Firmo, L. A. (2013). Bases do comprometimento organizacional: um estudo comparativo em Empresas Juniores. Gestão e Sociedade, 7(16), 51-69. doi:10.21171/ges.v7i16.1626

Fernandes, H. A., \& Ferreira, M. C. (2009). O impacto dos valores pessoais e organizacionais no comprometimento com a organização. Psico-USF, 14(3), 341-354. doi:10.1590/S1413-82712009000300010

Fleming, P., \& Spicer, A. (2014). Power in Management and Organization Science. The Academy of Management Annals, 8(1), 237-298. doi:10.1080/19416520.2014.875671

French, J. R. P. Jr., \& Raven, B. (1959). The bases of social power. In D. Cartwright (Ed.). Studies in social power (pp. 150-167). Ann Arbor: University of Michigan Press.

Giglio, E., Pugliese, R. L., \& Silva, R. M. (2012). Análise dos conceitos de poder nos artigos brasileiros sobre redes. Revista de Administração da UNIMEP, 10(3), 51-69. Recuperado de http://www.redalyc.org/pdf/2737/273724912003.pdf

Guimarães, V. F., \& Martins, M. C. F. (2008). Bases de poder do supervisor, conflitos intragrupais e comprometimento organizacional e com a equipe. Rev. Psicol., Organ. Trab., 8(2), 54-78. Recuperado de https://periodicos.ufsc.br/index.php/rpot/article/view/10159/9395

Hair, J. F. Jr., Anderson, R. E., Tathan, R. L., \& Black, W. C. (2005). Análise Multivariada de dados (5a ed.). Porto Alegre: Bookman.

Hair, J. F. Jr., William, B., Babin, B., \& Anderson, R. E. (2009). Análise multivariada de dados (6a ed.). Porto Alegre: Bookman.

Hinkin, T. R., \& Schriesheim, C. A. (1989). Development and application of new scales to measure the French and Raven (1959) bases of social power. Journal of Applied Psychology, 74(4), 561-567. doi:10.1037/0021-9010.74.4.561

Hobbes, T. (1988). Leviatã ou matéria, forma e poder de um estado eclesiástico e civil (J. P. Monteiro, \& M. B. N. Silva, Trad.). São Paulo: Nova Cultural. (Obra original publicada em 1651)

Johnson, P. E., \& Evans, J. P. (1997). Power, Communicator Styles, and Conflict Management Styles: A Web of Interpersonal Constructs for the School Principal. International Journal of Educational Reform, 6(1), 40-53. Recuperado de https://eric.ed.gov/?id=EJ544241 
Johnson, P. E., \& Scollay, S. J. (2000). Scholl-based, decision-making councils: conflict, leader power and social influence in the vertical team. Journal of Educational Administration, 39(1), 47-66. doi:10.1108/09578230110380733

Llapa-Rodríguez, E. O., Trevizan, M. A., \& Shinyashiki, G. T. (2008). Reflexões conceituais sobre comprometimento organizacional e profissional no setor saúde. $R L A E, 16(3), 484-$ 488. Recuperado de http://www.scielo.br/pdf/rlae/v16n3/pt_24.pdf

Lopes, F. T., Carrieri, A., \& Saraiva, L. A. S. (2013). Relações entre poder e subjetividade em uma organização familiar. $\quad O \& S, \quad 20(65), \quad 225-238$. doi:10.1590/S198492302013000200003

Luke, S. (1980). O poder. Brasília: Universidade de Brasília.

Maciel, C. O., \& Camargo, C. (2011). Comprometimento, satisfação e cooperação no trabalho: evidências da primazia dos aspectos morais e das normas de reciprocidade sobre o comportamento. $R A C, 15(3), 433-453$. doi:10.1590/S1415-65552011000300005

Magalhães, M. O. (2008). Generatividade e vínculos com a carreira e a organização: problematizando as bases do comprometimento organizacional. Rev. bras. orientac. Prof., 9(2), 67-80. Recuperado de http://pepsic.bvsalud.org/scielo.php?script=sci_arttext\&pid=S167933902008000200007

Maquiavel, N. (1972). O Príncipe. Lisboa: Publicações Europa-América. (Obra original publicada em 1532)

Marques, É. P., \& Marques, A. L. (2014, setembro). Comprometimento organizacional e personalidade: considerações sobre a influência dos traços no comprometimento. Anais do Encontro da ANPAD - ENANPAD, Rio de Janeiro, RJ, Brasil, 38.

Martins, M. C. F. (2008). Bases do poder organizacional. In M. M. M. Siqueira (Org.), Medidas do comportamento organizacional (pp. 21-28). Porto Alegre: Artmed.

Marx, K. (2006). Manuscritos Econômicos-Filosóficos. São Paulo: Martin Claret Ltda.

Mendonça, J. R. C., \& Dias, S. M. R. C. (2006). De French e Raven (1959) ao modelo poder/interação de influência interpessoal: uma discussão sobre poder e influência social. Cadernos EBAPE.BR, 4(4), 1-19. doi:10.1590/S1679-39512006000400009

Meyer, J. P., \& Allen, N. J. (1991). A three-component conceptualization of organizational commitment. Human Resource Management Review, 1(1), 61-89. doi:10.1016/10534822(91)90011-Z 
Mintzberg, H. (1983). Power in and around organizations. New Jersey: Prentice-Hall.

Morgan, G. (2000). Imagens da organização. São Paulo: Atlas.

Morgan, G. (2002). Imagens da organização: edição executiva (2a ed.). São Paulo: Atlas. (Obra original publicada em 1943)

Mossoró. (2009). Lei complementar n. 037, de 14 de dezembro de 2009. Dispõe sobre a Guarda Civil Municipal, nos termos do art. 144, §8 ${ }^{\circ}$, da Constituição Federal, e no art. 215 da Lei Orgânica do Município, e dá outras providências. Recuperado de http://www.prefeiturademossoro.com.br/jom/jom47b.pdf

Mossoró. (2014). Lei complementarn. 098, de 24 de janeiro de 2014. Institui o Plano de Cargos, Carreira e Remunerações - PCCR dos Guardas Civis Municipais do Município de Mossoró, instituída pela Lei Complementar nº 037 de 14 de dezembro de 2009 e dá $\begin{array}{llll}\text { outras } & \text { providências. } & \text { Recuperado }\end{array}$ http://www.prefeiturademossoro.com.br/jom/jom237.pdf

Paiva, K. C. M., \& Morais, M. M. S. (2012). Comprometimento organizacional: um estudo com docentes do CEFET-MG. G\&T, 12(1), 74-101. doi:10.20397/21776652/2012.v12i1.326

Paiva, K. C. M., Dutra, M. R. S., \& Luz, T. R. (2015). Comprometimento organizacional de trabalhadores de call center. RAUSP, 50(3), 310-324. doi:10.5700/rausp1202

Paz, M. G. T., \& Neiva, E. R. (2014). O Poder discriminante da escala de configuração do poder organizacional na perspectiva macro organizacional e sua utilização como instrumento de caracterização do perfil cultural das organizações. Psicol. Organ. Trab., 14(2), 153168. Recuperado de http://pepsic.bvsalud.org/pdf/rpot/v14n2/v14n2a03.pdf

Porto, D. L., Vasconcelos, C. R. P., Silva, R. M., \& Paulino, R. D. (2010, agosto). Estudo exploratório sobre as bases de poder e o comprometimento organizacional afetivo. Anais do Congresso Nacional de Excelência em Gestão: energia, inovação, tecnologia e complexidade para a gestão sustentável, Rio de Janeiro, RJ, Brasil, 6.

Rahim, M. A. (1989). Relationships of Leader Power to Compliance and Satisfaction with Supervision: Evidence from a National Sample of Managers. Journal of Management, 15(4), 545-556. doi:10.1177/014920638901500404

Raven, B. H. (1993). The bases of power: origins and recent developments. Journal of Social Issues, 49(4), 227-251. doi:10.1111/j.1540-4560.1993.tb01191.x

Reinert, M., Maciel, C. O., \& Candatten, F. (2011). Intersecções entre clima e comprometimento organizacional: uma análise dos antecedentes, dimensionalidade e 
Silva, A. W. P. da, Veiga Neto, A. R., Lima Coelho, A. L. de A., \& Castro, A. B. de (2019)

encontros entre construtos. Revista Alcance - Eletrônica, 18(2), 167-184. doi:10.14210/alcance.v18n2.p167-184

Ribeiro, A. N., \& Garcia, F. C. (2015). Relações de Poder e Gênero no Alto Comando da Polícia Militar de Minas Gerais: Uma Análise da Percepção das Mulheres Policiais. Teoria e Prática em Administração, 5(1), 53-79. Recuperado de http://periodicos.ufpb.br/index.php/tpa/article/view/21175/13546

Robbins, S. P., Judge, T. A., \& Sobral, F. (2010). Comportamento organizacional (14a ed.). São Paulo: Pearson Prentice Hall.

Rodrigues, A. C. A., \& Bastos, A. V. B. (2010). Problemas conceituais e empíricos na pesquisa sobre comprometimento organizacional: uma análise crítica do modelo tridimensional de J. Meyer e N. Allen. Rev. Psicol., Organ. Trab., 10(2), 129-144. Recuperado de https://periodicos.ufsc.br/index.php/rpot/article/view/22214

Rosa, G. R., \& Kamimura, Q. P. (2012, dezembro). O poder das redes sociais: uma nova abordagem. Anais do International Congress on University-Industry Cooperation: Innovation and Sustainability in Latin America, Taubate, SP, Brasil, 4.

Rosário, D. K. M. H., Queiroz, K. C. F., \& Martins, J. C. O. (2015). Relações entre poder e comprometimento afetivo na gestão pública. RaUnP, 7(1), 77-88. Recuperado de https://repositorio.unp.br/index.php/raunp/article/view/748/681

Rowe, D. E. O., \& Bastos, A. V. B. (2010). Vínculo com a carreira e produção acadêmica: comparando docentes de IES públicas e privadas. RAC, 14(6), 1011-1130. doi:10.1590/S1415-65552010000700003

Sampieri, R. H., Collado, C. F., \& Lucio, P. B. (2006). Metodologia de Pesquisa (3ed.). São Paulo: McGraw-Hill.

Santos, G. A. F., \& Claro, J. A. C. S. (2014). Poder e Política nas Organizações, à Luz das Teorias Organizacionais: Um Estudo Bibliométrico nos Anais do EnANPAD. Rev. Elet. Gestão e Serviços, 5(1), 812-826. doi:10.15603/2177-7284/regs.v5n1p812-826

Santos, N. G., Fo. (2002). O poder nas Organizações: Vertentes de análise. CienteFico, 1. Recuperado de http://www.ebah.com.br/content/ABAAAfZmAAK/poder-nasorganizacoes-vertentes-analise

Saraiva, L. A. S., \& Santos, A. V. (2011). Estratégias de poder de trabalhadores industriais. Rev. Adm. Mackenzie, 12(4), 15-43. doi:10.1590/S1678-69712011000400002

Schein, E. H. (1982). Psicologia Organizacional. Rio de Janeiro: Prentice-Hall do Brasil Ltda. 
Schirrmeister, R., \& Limongi-França, A. C. (2012). A qualidade de vida no trabalho: relações com o comprometimento organizacional nas equipes multicontratuais. Rev. Psicol., Organ. Trab., 12(3), 283-298. Recuperado de http://pepsic.bvsalud.org/scielo.php?script=sci_arttext\&pid=S198466572012000300004

Schriesheim, C. A., Hinkin, T. R., \& Podsakoff, P. M. (1991). Journal of Applied Psychology, 76(1), 106-114. doi:10.1037/0021-9010.76.1.106

Simosi, M. (2013). Trajectories of organizational commitment: A qualitative study in a Greek public sector organization. IJCCM, 13(1), 111-130. doi:10.1177/1470595812452637

Siqueira, V. T. A., \& Kurcgant, P. (2012). Satisfação no trabalho: indicador de qualidade no gerenciamento de recursos humanos em enfermagem. Rev Esc Enferm USP, 46(1), 151157. doi:10.1590/S0080-62342012000100021

Souza, K. B. M. (2012). Comprometimento organizacional dos docentes de uma escola particular de ensino do Rio Grande do Norte (Dissertação de mestrado). Universidade Potiguar, Natal, RN, Brasil.

Traldi, M. T. F., \& Demo, G. (2012). Comprometimento, bem-estar e satisfação dos professores de administração de uma universidade federal. REAd, 18(2), 290-316. doi:10.1590/S1413-23112012000200001

Weber, M. (1991). Economia e sociedade. Brasília: Editora da UnB. (Obra original publicada em 1919)

Weber, M. (2008). Os três tipos puros de dominação legítima. Rio de Janeiro: VGuedes Multimídia.

Yukl, G. A. (1994). Leadership in Organizations (3a ed.). New Jersey: Prentice-Hall.

Zanardi, E., Pilatti, L., Santos, C., Godoi, H., \& Claumann, P. (2015). Correlações entre qualidade de vida no trabalho e comprometimento organizacional: estudo em uma unidade de varejo de vestuário na cidade de Joinville/SC. Revista Produção Online, 15(2), 573-600. doi:10.14488/1676-1901.v15i2.1928 